Louisiana State University

LSU Digital Commons

6-1-2012

\title{
Food deprivation explains effects of mouthbrooding on ovaries and steroid hormones, but not brain neuropeptide and receptor mRNAs, in an African cichlid fish
}

\author{
Brian P. Grone \\ Stanford University \\ Russ E. Carpenter \\ Stanford University \\ Malinda Lee \\ Stanford University \\ Karen P. Maruska \\ Stanford University \\ Russell D. Fernald \\ Stanford University
}

Follow this and additional works at: https://digitalcommons.Isu.edu/biosci_pubs

\section{Recommended Citation}

Grone, B., Carpenter, R., Lee, M., Maruska, K., \& Fernald, R. (2012). Food deprivation explains effects of mouthbrooding on ovaries and steroid hormones, but not brain neuropeptide and receptor mRNAs, in an African cichlid fish. Hormones and Behavior, 62 (1), 18-26. https://doi.org/10.1016/j.yhbeh.2012.04.012

This Article is brought to you for free and open access by the Department of Biological Sciences at LSU Digital Commons. It has been accepted for inclusion in Faculty Publications by an authorized administrator of LSU Digital Commons. For more information, please contact ir@lsu.edu. 


\title{
Food deprivation explains effects of mouthbrooding on ovaries and steroid hormones, but not brain neuropeptide and receptor mRNAs, in an African cichlid fish
}

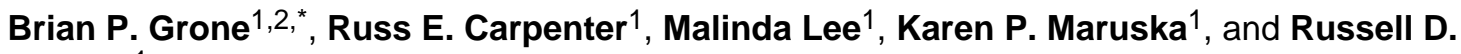 \\ Fernald $^{1}$ \\ ${ }^{1}$ Biology Department, Stanford University, Stanford, CA 94305-5020
}

\begin{abstract}
Feeding behavior and reproduction are coordinately regulated by the brain via neurotransmitters, circulating hormones, and neuropeptides. Reduced feeding allows animals to engage in other behaviors important for fitness, including mating and parental care. Some fishes cease feeding for weeks at a time in order to provide care to their young by brooding them inside the male or female parent's mouth. Maternal mouthbrooding is known to impact circulating hormones and subsequent reproductive cycles, but neither the full effects of food deprivation nor the neural mechanisms are known. Here we ask what effects mouthbrooding has on several physiological processes including gonad and body mass, brain neuropeptide and receptor gene expression, and circulating steroid hormones in a mouthbrooding cichlid species, Astatotilapia burtoni. We ask whether any observed changes can be explained by food deprivation, and show that during mouthbrooding, ovary size and circulating levels of androgens and estrogens match those seen during food deprivation. Levels of gonadotropin-releasing hormone $1(\mathrm{GnRH} 1) \mathrm{mRNA}$ in the brain were low in fooddeprived females compared to controls and in mouthbrooding females compared to gravid females. Levels of mRNA encoding two peptides involved in regulating feeding, hypocretin and cholecystokinin, were increased in the brains of food-deprived females. Brain mRNA levels of two receptors, GnRH Receptor 2 and NPY receptor Y8c, were elevated in mouthbrooding females compared to the fed condition, but NPY receptor Y8b mRNA was differently regulated by mouthbrooding. These results suggest that many, but not all, of the characteristic physiological changes that occur during mouthbrooding are consequences of food deprivation.
\end{abstract}

\section{Keywords}

feeding; reproduction; parental care; teleost; cichlid; testosterone; estradiol; neuropeptide; NPY; GnRH

${ }^{*}$ Corresponding author: Brian Grone (bgrone@stanford.edu).

${ }^{2}$ Present address: Department of Psychiatry and Behavioral Sciences, Center for Sleep Sciences, Stanford University, Palo Alto, California, 94305, USA.

Publisher's Disclaimer: This is a PDF file of an unedited manuscript that has been accepted for publication. As a service to our customers we are providing this early version of the manuscript. The manuscript will undergo copyediting, typesetting, and review of the resulting proof before it is published in its final citable form. Please note that during the production process errors may be discovered which could affect the content, and all legal disclaimers that apply to the journal pertain. 


\section{Introduction}

Reproduction in vertebrates requires a substantial energy investment, especially by females, for production of eggs and care of developing young. Parental care, defined as any form of behavior by one or both parents following fertilization that is likely to increase offspring fitness, is a major energetic cost of reproduction (Clutton-Brock, 1991). Some species forgo feeding entirely during a period of intense parental care, making further demands on metabolism. However, little is known about the changes in neurotransmitters and hormones that accompany parental care and regulate food intake during this energetically costly time. We analyzed this tradeoff in a species of cichlid fish, Astatotilapia burtoni, in which the female broods the developing eggs in her mouth for two weeks, during which she doesn't eat (Fernald and Hirata, 1979). To clarify the neural mechanisms underlying mouthbrooding, we measured expression of genes in the brain that regulate feeding and reproduction as well as circulating sex steroid hormone levels and ovary growth during food deprivation and mouthbrooding.

Feeding and reproduction are coordinately regulated by the brain (Tena-Sempere, 2007). With few exceptions, hormones and neuropeptides that inhibit reproduction tend to stimulate feeding (Schneider, 2004), and food deprivation affects the entire brain-pituitary-gonadal axis (Berriman et al., 1992; Loucks and Heath, 1994). To be reproductively successful, animals must balance the competing demands of feeding and reproduction. The mechanisms that regulate this balance must directly influence the individual's chances for survival and ultimately its reproductive fitness. Many of the neuropeptides known to regulate feeding and reproduction are conserved from teleosts to mammals and in many cases their expression is regulated by reproductive cycles and food intake.

The superorder Teleostei is the most diverse group of vertebrates and parental care patterns in these fishes span a wide range of behaviors (Gross and Sargent, 1985). Many cichlid fish species provide parental care, often in the form of mouthbrooding, and the brooding parent can be either the male or female or both (Oppenheimer, 1970). Mouthbrooding fishes undergo a particularly dramatic change in behavior linked to parenting: after spawning they consume little or no food for a period of weeks while holding and caring for their offspring inside their mouths (Fryer and Iles, 1972; Oppenheimer, 1970). In a study of 254 species of fish, those providing mouthbrooding or other parental care were highly likely to have empty stomachs (Arrington et al., 2002), suggesting that mouthbrooding has a significant impact on life history and energy balance. In female cichlids, mouthbrooding can cause a loss of body mass, delayed ovarian cycles, and delays in subsequent spawning (Smith and Wootton, 1994, 1995; Smith and Haley, 1987; Tacon, 1996). Thus, among cichlids, metabolism and physiology, as well as behavior, differ greatly between interspawning periods of energy storage and mouthbrooding periods of energetically demanding food deprivation.

The reproductive physiology, behavior, and neuroendocrinology of an African mouthbrooding cichlid species native to Lake Tanganyika, Astatotilapia burtoni, has been extensively analyzed, making it a particularly useful model for asking questions about the interactions between physiology and behavior (Fernald, 2009; Fernald and Hirata, 1977 ; Francis et al., 1993; Hofmann and Fernald, 2000). For a period of about two weeks following spawning, female $A$. burtoni carry clutches of 30 to 50 eggs in their mouths (Fernald and Hirata, 1979). Although some cichlids do feed themselves or their young while mouthbrooding, $A$. burtoni females typically do not eat during the entire period of mouthbrooding, except in rare cases of brood cannibalization. A. burtoni females undergo several known behavioral and neural changes dependent on their reproductive state. Behaviorally, for example, when female A. burtoni are given a choice between territorial and nonterritorial males, non-gravid females spend equal amounts of time near both, but 
gravid females prefer to spend time near territorial males and, among territorial males, prefer more active individuals (Clement et al., 2005). Physiologically, compared to brooding females, spawning or gravid females have larger hypophysiotropic gonadotropin-releasing hormone (GnRH1) neuron somata (White and Fernald, 1993), larger ovaries, and higher circulating levels of sex steroid hormones (Maruska and Fernald, 2010). The neural mechanisms responsible for these shifts in behavior and physiology are unknown but may include modulation of peptide release, receptor abundance, or gene expression levels in the brain.

Food deprivation has been shown to up- or down-regulate production of specific neuropeptides in many species (Schwartz et al., 2000), but its effects in A. burtoni are not well described. Previous reports in several cichlid species have emphasized the behavioral condition of mouthbrooding without investigating the associated, and often obligatory, food deprivation (Kishida and Specker, 2000; Mrowka, 1984; Smith and Haley, 1988). Since mouthbrooding is associated with reduced food intake, we predicted that steroid hormone and neuropeptidergic changes characteristic of food deprivation may appear in female $A$. burtoni while they are mouthbrooding. Alternatively, mouthbrooding species like $A$. burtoni may have developed adaptations to compensate for food deprivation during the brooding period, such that changes in the brain are different than those seen during normal food deprivation. Direct tests of these alternative hypotheses, however, have been lacking.

We asked whether the physiological phenotype of mouthbrooding $A$. burtoni females could be explained by the effects of food deprivation. We found that steroid hormones and brain neuropeptide and receptor genes linked to feeding and reproduction are regulated in response to food deprivation in female $A$. burtoni. Our results indicate that food deprivation may be sufficient to account for the physiological and hormonal changes seen during mouthbrooding, but not all of the neurobiological changes.

\section{Materials and Methods}

\section{Animals}

A laboratory-bred population of Astatotilapia burtoni derived from a wild-caught stock was housed in aquaria under conditions similar to those of their natural environment: $\mathrm{pH} 7.8-8.2$, temperature $28^{\circ} \mathrm{C}$, and 12 hour light/12 hour dark cycle with full-spectrum illumination (Fernald and Hirata, 1977). Gravel covered the floor of the aquaria, and terra-cotta pot halves atop the gravel served as shelters, and facilitated the establishment and maintenance of territories among males. Fish were fed each morning with cichlid pellets and flakes (AquaDine, Healdsburg, CA). Amount of food varied with experimental treatment as described below. Standard length (SL), body mass (BM), and gonad mass (GM) of all animals were measured at the time of sacrifice and gonadosomatic index (GSI) was calculated as [(gonad mass/body mass)*100]. For all dissections, fish were briefly anesthetized in iced tank water, sacrificed by rapid cervical transection and brains were immediately removed, rapidly frozen in $1.5 \mathrm{~mL}$ microcentrifuge tubes on dry ice, and stored at $-80^{\circ} \mathrm{C}$. This rapid freezing of dissected tissues and subsequent storage at $-80^{\circ} \mathrm{C}$ is known to minimize RNA degradation \{Barton, 1993 \#4127; Yasojima, 2001 \#4119\}. All experiments were in compliance with the Animal Care and Use Guidelines at Stanford University and approved by the local Administrative Panel on Laboratory Animal Care.

\section{Experimental Treatments}

Experiment 1: Mouthbrooding vs. Food Deprivation-To compare the physiological effects of mouthbrooding to those of food deprivation, we removed eggs from the mouths of some females after spawning and compared these females to other females 
with intact broods. Females between $4.1 \mathrm{~cm}$ and $6.0 \mathrm{~cm}$ Standard Length (SL) were chosen from community tanks within one day following spawning. Females were randomly assigned to one of three groups: (1) mouthbrooding females that retained their developing embryos for the duration of the experiment, (2) brooding females whose eggs were removed from their mouths that were then returned to a daily feeding schedule, and (3) brooding females whose eggs were removed that were subsequently deprived of food for the duration of the experiment. All females were housed solely with other females in the same treatment group and were sacrificed 14 days after spawning. Brains were removed, rapidly frozen on dry ice and stored at $-80^{\circ} \mathrm{C}$ until analysis. Blood was collected following decapitation via capillary tubes and centrifuged for 10 minutes $(8000 \mathrm{rpm})$. Plasma was removed, frozen on dry ice, and stored at $-80^{\circ} \mathrm{C}$ until hormone assays were performed (see below). Plasma androgens and estrogens were measured in these females as a physiological indicator of reproductive state to test whether food deprivation would mimic the lower circulating steroid levels, likely due to small ovaries, that are often seen in mouthbrooding females.

Experiment 2: Mouthbrooding vs. Gravid-To test how female reproductive status influenced brain gene expression, mouthbrooding and gravid (sexually receptive) females from 4.0 to $5.6 \mathrm{~cm}$ SL were selected from large, mixed-sex community tanks and immediately sacrificed. Females brooding fully developed fry about $5-7 \mathrm{~mm}$ in length, which take 10-13 days post-fertilization to develop (Fernald and Hirata, 1979), were selected as mouthbrooders. Gravid females were initially selected by body shape (distended abdomen, indicating high GSI and large oocytes) and reproductive status was confirmed at sacrifice by gonad dissection. GSI values for gravid females were all $>4.5$. Fish in these tanks were fed a standard amount of food each morning, equal to approximately $2 \%$ of body weight on average. Brain samples were collected as described above for Experiment 1.

Experiment 3: Female Food Deprivation-To test the effects of prolonged food deprivation on female $A$. burtoni, females were either fed normally or were food deprived for 4 weeks. To ensure that females began the experiment in similar reproductive states, mouthbrooding females with either eggs or fry in their mouths were selected from community tanks. These brooding females then had their eggs and fry removed from their mouths and were assigned to either the food-deprived or the control tank. All females were weighed and measured at the beginning of the experiment. Food-deprived fish received no food and controls were fed normally (the fed group received about $2 \%$ of body mass every day) during the same 4-week period. To assess changes in body mass during food deprivation, body mass was recorded along with gonad mass at the time of sacrifice. Brain samples were collected as described above for Experiment 1. To assess body composition in fed and food deprived females, fish were weighed both wet and dry at the end of the 4-week experiment. Carcasses were weighed immediately after sacrifice (wet weight), and again after overnight placement in a drying oven to deplete the bodies of moisture (dry weight). Dry:wet weight ratios were then calculated as a relative measure of body fat content and condition.

\section{Quantitative RT-PCR (qRT-PCR)}

Brain mRNA levels were measured by quantitative reverse transcription-PCR (qRT-PCR) with the MyIQ Real-Time PCR Detection System (Bio-Rad Laboratories, Hercules, CA). Immediately after thawing (on ice) and homogenization of brain tissues, total RNA, free from genomic DNA contamination, was extracted using Qiagen RNeasy Plus Mini Kits (Qiagen, Valencia, CA), and $\sim 1 \mu \mathrm{g}$ total RNA for each brain sample was used to make cDNA by iScript reverse transcription (Bio-Rad Laboratories, Hercules, CA). cDNA was then diluted to the desired concentration in nuclease-free water for qRT-PCR. 
Quantitative RT-PCR primers for all genes were designed with Vector NTi (Invitrogen, Carlsbad, CA) and PrimerQuest (Integrated DNA Technologies, Coralville, IA) software (Table 1). All qRT-PCR primers were designed to avoid dimers or hairpin structures and to have similar melting temperatures $\left(\mathrm{ca} .60^{\circ} \mathrm{C}\right.$ ) and GC content (ca. $50 \%$ of residues). Primers used to measure control genes g3pdh (AF123727) and actin (JF826504) were identical to those used previously for $A$. burtoni (Zhao and Fernald, 2005).

qRT-PCR was performed in 30- $\mu \mathrm{L}$ duplicate reactions using a BioRad Real-Time PCR system with 1X IQ SYBR Green Supermix (Bio-Rad Laboratories, Hercules, CA), $0.25 \mu \mathrm{M}$ of each primer, and $2.5 \mathrm{ng} / \mu \mathrm{L}$ cDNA (RNA equivalent). Each amplicon was specifically amplified, as demonstrated by single peaks in melt curves for each reaction product. Fluorescence data were processed using Real-time PCR Miner software (Zhao and Fernald, $2005)$ to calculate threshold cycle number (CT) and amplification efficiency for each sample. CT values were below 30 for all reactions. To normalize mRNA levels, values for each sample were divided by either $g 3 p d h$ or actin concentration values, depending on the experiment.

\section{Statistical analyses}

Data were analyzed with GraphPad Prism 5 (Graph Pad Software Inc., San Diego, CA) using a two-tailed unpaired $t$ test or one-way ANOVA followed by Tukey's or Student Newman-Keuls (SNK) post hoc tests. Values are expressed as mean \pm SEM or mean \pm SD. Normality was confirmed using D'Agostino \& Pearson omnibus normality test and equality of variance by $\mathrm{F}$ test. In cases where homogeneity of variance or normality assumptions could not be met, even after transformation, Mann-Whitney U or Kruskal-Wallis (KW) tests were used to compare groups, followed by post hoc Dunn's tests for multiple comparisons.

\section{Steroid Hormone Assays}

Plasma androgens and estrogens were measured from females in Experiment 1 using commercially available Enzyme Immunoassay (EIA) kits (Cayman Chemical, Inc.) that were previously validated for $A$. burtoni (Maruska and Fernald, 2010). The Testosterone EIA Kit primarily recognizes testosterone (T) and has some cross-reactivity with other androgens (A). The Estradiol EIA Kit primarily recognizes $17 \beta$-estradiol $\left(\mathrm{E}_{2}\right)$ and has some cross-reactivity with other estrogens (E). A $6.5 \mu \mathrm{l}$ sample of plasma from each subject was extracted three times using $200 \mu \mathrm{l}$ of diethyl ether and evaporated under a fume hood prior to re-constitution in EIA assay buffer (1:35 dilution). EIA kit protocols were then strictly followed, plates were read at $405 \mathrm{~nm}$ using a microplate reader $\left(\mathrm{UV}_{\max }\right.$ Microplate Reader, Molecular Devices), and steroid concentrations determined from standard curves. All samples were assayed in duplicate and intra-assay coefficients of variation (CV) were: androgen (9.8\%); estrogen (9.2\%).

\section{Results}

\section{Experiment 1: Mouthbrooding vs. Food Deprivation}

Fed females had significantly higher GSI values (mean \pm SEM; $2.657 \pm 0.3283$ ) compared to both mouthbrooding $(0.6263 \pm 0.1186)$ and food-deprived animals $(0.8310 \pm 0.09492)$ (KW statistic 14.79, $\mathrm{p}=0.006$; Dunn's post test, $\mathrm{p}<0.05$ ) (Fig 1). Body weights did not differ among groups (KW statistic $2.643, \mathrm{p}=0.2668$ ).

Levels of gnrhr 2 mRNA in the brain were significantly higher (KW statistic 6.705 , $\mathrm{p}=0.0350$; Dunn's post test, $\mathrm{p}<0.05$ ) in mouthbrooding females compared to fed females, but not different from the food-deprived condition. npyry $8 b$ levels were significantly higher in mouthbrooding females compared to food deprived females (KW statistic 6.100, $\mathrm{p}=0.0474$; 
Dunn's post test, $\mathrm{p}<0.05)$, but neither group was different compared to fed females. npyry $8 \mathrm{c}$ levels were also significantly higher in mouthbrooding females than in the fed females, but food-deprived females were not different from the other two groups (KW statistic 8.508, $\mathrm{p}=0.0142$; Dunn's post test, $\mathrm{p}<0.05$ ) (Fig. 1). A significant outlier (Grubb's test, $\mathrm{p}<0.01$ ) was removed from the food deprived group for both gnrhr 2 and npyry $8 b$. No differences among groups were found for any of the other mRNA expression levels tested (see Table 2).

Plasma concentrations of androgens (A) and estrogens (E) were higher in females that had their eggs removed from their mouths after spawning and were then fed, compared to both mouthbrooding females that retained their developing embryos and females that had their eggs removed and were food-deprived (ANOVA, A: $\mathrm{F}_{(2,24)}=4.64, \mathrm{p}=0.020$, SNK, $\mathrm{p}<0.05$; $\left.\mathrm{E}: \mathrm{F}_{(2,24)}=7.05, \mathrm{p}=0.004, \mathrm{SNK}, \mathrm{p}<0.05\right)$ (Fig. 2). There was also a positive correlation between plasma $\mathrm{A}$ and $\mathrm{E}$ concentrations in all animals (Pearson product moment, $\mathrm{r}=0.87, \mathrm{p}$ $<0.001)$.

\section{Experiment 2: Mouthbrooding vs. Gravid}

Gravid females from community tanks had $\sim 8$-fold higher GSI $(6.327 \pm 0.3775, \mathrm{~N}=8)$ than mouthbrooding females $(0.744 \pm 0.0129, \mathrm{~N}=8)$ (Mann-Whitney test; $\mathrm{p}=0.0002)$, and there was significantly more variance among the gravid females than among the mouthbrooders ( $\mathrm{F}$ test; $\mathrm{p}=0.0109$ ). There was no difference in average body mass between mouthbrooding $(2.514 \mathrm{~g} \pm 0.206 \mathrm{~g}, \mathrm{~N}=8)$ and gravid females $(3.036 \mathrm{~g} \pm 0.294 \mathrm{~g}, \mathrm{~N}=8)$ (two-tailed t Test, $\mathrm{p}=$ 0.168 ). The control gene $g 3 p d h$ was used to normalize other genes in Experiment 2 because $g 3 p d h$ levels did not differ between mouthbrooding and gravid females (Mean \pm SEM mouthbrooders: 3.097e-006 $\pm 3.805 \mathrm{e}-007 \mathrm{~N}=8$; gravid: $3.870 \mathrm{e}-006 \pm 3.033 \mathrm{e}-007, \mathrm{~N}=8$; twotailed t-test, $\mathrm{p}=0.1346$ ).

Whole brain mRNA levels of gnrh1 were significantly higher in gravid compared to mouthbrooding females (Table 3). cck and hcrt mRNA levels, on the other hand, were significantly higher in mouthbrooding compared to gravid females. There were no differences between mouthbrooding and gravid females for any other measured gene (Table $3)$.

\section{Experiment 3: Female Food Deprivation}

As expected, female body mass increased in fed animals (percent change in mass: $19.325 \pm$ $1.159, \mathrm{~N}=9)$ and decreased in food-deprived animals $(-9.112 \pm 1.159, \mathrm{~N}=8)$ over the 4-week experimental period. Weight changes for the two groups were statistically different (twotailed $\mathrm{t}$ test; $\mathrm{p}=2.647 \times 10^{-9}$ ). Also as expected, Dry:Wet weight ratio was significantly lower in food-deprived females $(21.864 \pm 0.159)$ than in fed controls $(23.820 \pm 0.750)$ (Mann-Whitney test; $\mathrm{P}=0.0206$ ).

GSI was also significantly lower in food-deprived females $(0.288 \pm 0.0355, \mathrm{~N}=8)$ compared to fed controls ( $3.933 \pm 0.791 ; \mathrm{N}=9$; Mann-Whitney test; $\mathrm{p}=0.0055)$.

In this experiment, gnrh1 mRNA levels were significantly higher in brains of fed females than in food-deprived females (two tailed t test, $\mathrm{t}$ stat $=4.0596, \mathrm{p}=0.0012$ ). There were no other differences in brain gene expression between fed and food-deprived females (Table 4).

\section{Discussion}

Our experiments revealed some of the consequences of mouthbrooding and food deprivation on physiology and mRNA expression of several genes involved in neurohormonal pathways that regulate feeding and reproduction. Comparing mouthbrooding and fed females (Experiment 1) showed that, compared to fed females, mouthbrooding female A. burtoni had 
higher brain expression of two receptor mRNAs: one GnRH receptor, gnrhr2, that may influence behavior (Chen and Fernald, 2006) and one NPY receptor, npyry $8 c$. Interestingly, mRNA of one gene we tested, npyry $8 b$, was expressed at different levels in mouthbrooding and food deprived females, with greater expression in the mouthbrooding females. Comparing mouthbrooding females to gravid females (Experiment 2) showed that mouthbrooding females had low levels of the reproductive hormone gene gnrh1, consistent with a previous study (White et al., 2002), and high levels of two genes implicated in the regulation of feeding and metabolism, $c c k$ and hcrt. Finally, we found that four weeks of food deprivation was associated with lower levels of gnrh1 relative to fed controls (Experiment 3).

Further, we show that food deprivation and mouthbrooding both lead to low GSI and circulating gonadal steroid hormone levels. Whereas some previous investigators have speculated that developing fry may release a hormone to inhibit the brain-pituitary-gonad axis in mouthbrooding cichlids (Specker and Kishida, 2000), we found that the food deprivation effects of mouthbrooding are sufficient to explain the hormonal changes we observed. Collectively, these results suggest that food deprivation could be the causal factor in inhibiting ovarian development and steroid hormone levels, but that mouthbrooding also has distinct profiles of gene expression in the brain that cannot be explained simply by the effects of food deprivation.

Many neuropeptides controlling food intake in mammals are conserved in fish, where they also play roles in regulating feeding. For example, hypocretins/orexins (Hcrt/Orx) and neuropeptide Y (NPY) stimulate feeding in goldfish (Kauffman and Rissman, 2004; Temple et al., 2003), as in mammals (Clark et al., 1984; de Lecea et al., 1998; Sakurai et al., 1998). Several NPY Receptor lineages are present in vertebrates, including two NPYR Y8 paralogs that exist in teleost fish, including $A$. burtoni (Turovskaya, 2006), but have been lost in mammals and chickens (Salaneck et al., 2008). NPY receptor types Y1 and Y5 mediate feeding control in rodents (Hu et al., 1996; Pedrazzini et al., 1998), but the roles of NPYR Y8 receptors have not yet been elucidated. Peptide products of several genes inhibit feeding in both teleost fish and mammals. These prepropeptides include cholecystokinin (CCK), melanin-concentrating hormone $(\mathrm{MCH})$, pituitary adenylate cyclase activating peptide (PACAP) and proopiomelanocortin (POMC) (Cerda-Reverter et al., 2003; Gibbs et al., 1973; Himick and Peter, 1994; Matsuda et al., 2005b; Matsuda et al., 2006; Morley et al., 1992; Vergoni and Bertolini, 2000). Neuropeptides whose mRNA levels are regulated by feeding include the orexigenic peptides NPY (Lin et al., 2000; Narnaware and Peter, 2001) and hypocretin (HCRT) (Nakamachi et al., 2006), as well as anorexigenic neuropeptides like CCK (Peyon et al., 1999), MCH (Qu et al., 1996), and PACAP (Matsuda et al., 2005a). GnRH2 may coordinate feeding and reproduction in birds (Maney et al., 1997), mammals (Kauffman and Rissman, 2004; Temple et al., 2003), and fish (Matsuda et al., 2008; Volkoff et al., 1999), but its effects in $A$. burtoni are unknown. Two GnRH receptor forms (GnRHR1, GnRH-R2) in A. burtoni are expressed throughout the brain, where they could mediate neuromodulatory effects of GnRH peptides (Flanagan et al., 2007). Like the gnrh1 mRNA, the mRNA encoding kisspeptin receptor (kiss 1r), which regulates GnRH release, was significantly higher in brains of dominant male $A$. burtoni compared to subordinate males (Grone et al., 2010), but kiss1r mRNA has not yet been examined in females. All of these genes are candidates for regulation of reproductive systems in the brain of mouthbrooding A. burtoni females; interestingly, only a few of them were significantly regulated by mouthbrooding and food deprivation.

\section{Food-deprived vs. Mouthbrooding}

We found that plasma levels of $\mathrm{A}$ and $\mathrm{E}$ were significantly higher in $A$. burtoni females that had been fed following spawning compared to females that were mouthbrooding and food 
deprived ( 2fold for A, $\sim 4$ fold for E). This result is interesting in light of previous work on a closely related cichlid, Oreochromis mossambicus, which compared steroid hormone levels, but not brain mRNA levels, between mouthbrooding females and females who had spawned but had their eggs removed from their mouths the following day (Smith and Haley, 1988). Smith and Haley measured plasma steroid levels at 3, 5, 7, 10, 15, 20, and 25 days following spawning. Ten days after spawning, mouthbrooders had significantly lower plasma androgens ( 10fold) and estrogens ( $\sim 3$ fold) compared to non-mouthbrooders (Smith and Haley, 1988). Continuous mouthbrooding ended at about two weeks after spawning, and the $\mathrm{A}$ and $\mathrm{E}$ differences were reversed: by 15 days after spawning, mouthbrooding females had much higher plasma A ( 7fold) and E ( 8fold) levels compared to had non mouthbrooded, suggesting that females have a rapid increase in both $\mathrm{E}$ and $\mathrm{A}$ (but not progesterone or 17aOH-progesterone) immediately after the mouthbrooding period (Smith and Haley, 1988). In the present study, we measured steroid levels when females were still mouthbrooding their fry, so our data are more comparable and consistent with the results from their 10-day rather than 15-day time point.

In another cichlid, Pseudocrenilabrus multicolor, removal of the fry decreased brood motivation, defined as the "readiness to take and keep the brood within the female's mouth", which is correlated with low hunger as measured by the amount of Tubifex worms ingested per unit time (Mrowka, 1984). The immediate resumption of feeding by P. multicolor females upon removal of the young, along with the delay in returning to normal levels of hunger, suggested that the physical presence of a brood inside the female's mouth combines with longer-term behavioral mechanisms to prevent feeding during mouthbrooding. Mouthbrooding males of Sarotherodon melanotheron, a biparental mouthbrooder, had decreased plasma $\mathrm{A}$ and $\mathrm{E}$ during the first week of brooding but increasing levels during the second week, peaking at the day of brood release, when A levels were 10-fold higher than during the first week and 2.5-fold higher than 10 days after release (Kishida and Specker, 2000). Species- or sex-specific variations could contribute to observed differences. Another factor contributing to variations between our results and the previous ones could be that we chose to measure A on day 14, but Kishida and Specker recorded elevated A levels on Day 11 and the day that fry were released, which ranged from Day 14 to Day 18. A previous study showed that, 12 days after fry release, recovering $A$. burtoni females have levels of testosterone, 11-ketotestosterone, and estradiol that are higher than mouthbrooding females but lower than gravid females (Maruska and Fernald, 2010). Our results confirm that $A$. burtoni females have low A and E levels at the end of mouthbrooding, but we don't yet know what happens to steroid levels during and immediately following the release of fry.

In our study, plasma A and E levels did not differ between females that were mouthbrooding and females that were food deprived for an equal length of time (14 days). Importantly, the food deprived females and the mouthbrooding females were reproductively synchronized because they both spawned at the beginning of the experiment. Therefore, the low gnrh1 mRNA and plasma A and E levels in mouthbrooding females may be explained simply by the effects of a two-week period of food deprivation, which is similarly associated with smaller ovaries, and therefore reduced reproductive readiness, in both female groups,. Thus, food availability likely regulates the amount of energy that can be used for ovarian recrudescence, which also has consequences for sex-steroid production. Other plasma and pituitary hormones that fluctuate with the breeding cycle in cichlids include prolactins, gonadotropins, and 17,20 $\beta$ progesterone (Tacon et al., 2000), and remain to be investigated in A. burtoni.

\section{Gravid vs. Mouthbrooding}

Mouthbrooding and gravid females showed differential brain expression of two genes involved with feeding, $c c k$ and hcrt. Increased expression of these two orexigenic peptide 
genes in mouthbrooding females corresponds with their decreased food intake. Reproduction is associated with two distinct periods in mouthbrooding cichlids: an investment phase (between mouthbrooding intervals) in which females store and use energy, and a consumption phase (mouthbrooding) of low turnover in which both oxygen consumption and food intake are much lower (Mrowka and Schierwater, 1988). The increased mRNA levels of $c c k$ and hcrt indicate that feeding circuits in the A. burtoni brain are modulated during mouthbrooding. Since hypocretin inhibits spawning behavior and stimulates feeding in goldfish (Hoskins et al., 2008), increases in hcrt could also serve to inhibit reproductive behaviors during mouthbrooding in $A$. burtoni. In contrast, we did not find differences in $c c k$ or hcrt levels between the different treatment groups in Experiment 1. Thus, the difference between mouthbrooding and gravid females suggests that the changes in $c c k$ and hcrt arise as a result of changes in physiology and metabolism following a prolonged energy storage phase rather than a rapid response after re-feeding.

In agreement with previous studies, we found lower gnrh1 levels in mouthbrooding females compared to gravid females (White et al., 2002), while expression of the other two GnRH mRNAs, gnrh2 and gnrh3, did not differ. If GnRH1 peptide levels decrease along with mRNA levels, activation of both GnRH receptor types in the pituitary is likely to be affected (Flanagan et al., 2007). In general, the reproductive axis is at its peak in gravid females, since they are preparing to spawn, and the subsequent changes in brain gene expression during mouthbrooding, including decreased gnrhl, and increased hcrt and $c c k$, may facilitate the transition to a nonreproductive period of parental caregiving.

\section{Food Deprivation}

The food-deprived females lost body mass and fat stores, and their ovaries were small even in proportion to their small body mass. The dry:wet weight ratio is a relative measure of body fat content because the loss in weight is primarily due to water, while the remaining weight is mainly lipids. Therefore, a high dry:wet percentage corresponds with high energy content, indicating that the fed animals were able to store excess energy as fat. Fooddeprived or mouthbrooding animals are therefore likely to require more time to replenish energy stores and mate again, potentially decreasing future reproductive fitness.

Food deprivation also led to low gnrh1 levels in Experiment 2. This negative effect is similar to that found in some other species. For example, food restriction also decreases the expression of gnrh1 mRNA in rats (Gruenewald and Matsumoto, 1993) and domestic chicken hens (Gallus domesticus) (Ciccone et al., 2007), but not male rhesus monkeys (Macaca mulatta) (Wahab et al., 2011) or female sheep (McShane et al., 1993). In contrast to food-restricted female musk shrews, which have reduced gnrh 2 mRNA levels in the midbrain and reduced GnRH2 peptide levels (Kauffman et al., 2006), there was no effect of food deprivation on gnrh2 mRNA in A. burtoni. Further work is needed to uncover the various roles, in both reproduction and feeding, of the three different $A$. burtoni $\mathrm{GnRH}$ peptides.

\section{Evolutionary Perspectives}

Mammalian reproduction and parental care differs substantially from the case in mouthbrooding fish. In mammals, feeding and lactation increase dramatically during pregnancy (Richard and Trayhurn, 1985; Trayhurn, 1989), while in mouthbrooding fish, feeding is prevented during the same time that parents must provide the most care for their offspring. Mammals typically have a fixed ovarian cycling time, whereas fish, including tropical mouthbrooding fish that breed year-round, have malleable ovarian cycle durations. Mouthbrooding may also differ from mammalian reproductive conditions in its repercussions on neuropeptide expression and signaling in the brain. Pregnancy, a similar 
period of heightened metabolic demand in mammals, decreases levels of mRNA encoding the orexigenic neuropeptides $\mathrm{MCH}$ and HCRT in the lateral hypothalamus of female rats (Garcia et al., 2003) while increasing feeding levels. Changes in feeding-related hormones including leptin, ghrelin, and insulin may either directly affect neuropeptides including GnRH and NPY or modulate the availability of metabolic fuels like glycogen and fatty acids, which can regulate female reproductive behavior and physiology in mammals (Schneider and Wade, 1989). Despite differences in energetic requirements during parental care in mammals and fish, reproductive readiness can affect feeding levels and expression of feeding neuropeptides across taxa, although the direction and magnitude of these changes is often species-specific.

Most studies of $A$. burtoni have used the same laboratory stock (LS) of fish derived from individuals caught in Lake Tanganyika in 1977 (Fernald and Hirata, 1977 ). In 2005 a new wild-caught stock (WS) of $A$. burtoni was collected at the south end of Lake Tanganyika (Renn et al., 2009). Females in the WS population are "good" mothers: compared to the LS line that has been propagated in the lab for about 40 generations, they are less likely to cannibalize offspring and more likely to successfully raise their offspring (Renn et al., 2009). WS females are also metabolically buffered against body mass changes: they gain body mass slower when fed and lose body mass slower when food deprived. WS fry also show greater maternal affiliation, staying closer to the brooding female regardless of whether she is WS or LS. These differences between wild-caught and lab-bred strains suggest that factors such as artificial selection, drift, and epigenetics may have contributed to a shift toward more rapid growth in favorable conditions along with decreased maternal care in LS fish.

\section{Conclusions}

Our results suggest that it is the food deprivation that occurs during mouthbrooding that generates much of the 'mouthbrooding effect' on the physiology of maternal cichlids. Food deprivation substantially suppresses ovarian development, and androgen and estrogen levels in $A$. burtoni, similar to the suppression seen during natural mouthbrooding. Future studies are needed to examine the neuroanatomical expression patterns and functional roles in feeding and mouthbrooding of the genes, including hcrt, $c c k$, npyry $8 b$, and npyry $8 c$, whose expression is regulated by feeding or mouthbrooding state. Our study also highlights the importance of including food-deprived groups as well as brooding and non-brooding groups in any future studies aimed at understanding the physiological, neural, and hormonal regulation of mouthbrooding in fishes. Doing so is the only way to clearly disambiguate the impact of a specific parental behavior state from the physiological consequences of food restriction.

\section{Acknowledgments}

We thank the reviewers for their insightful comments that helped us improve the manuscript. We are also grateful to Stanford Undergraduate studies (ML) and National Institutes of Health (NIH) Grants F32NS061431 (KPM), F32HD063234 (REC), and NS034950 (RDF) for funding this work.

\section{References}

Arrington DA, Winemiller KO, Loftus WF, Akin S. How often do fishes "run on empty"? Ecology. 2002; 83:2145-2151.

Berriman SJ, Wade GN, Blaustein JD. Expression of Fos-like proteins in gonadotropin-releasing hormone neurons of Syrian hamsters: effects of estrous cycles and metabolic fuels. Endocrinology. 1992; 131:2222-2228. [PubMed: 1425420] 
Cerda-Reverter JM, Schioth HB, Peter RE. The central melanocortin system regulates food intake in goldfish. Regul Pept. 2003; 115:101-113. [PubMed: 12972325]

Chen CC, Fernald RD. Distributions of two gonadotropin-releasing hormone receptor types in a cichlid fish suggest functional specialization. J Comp Neurol. 2006; 495:314-323. [PubMed: 16440293]

Ciccone NA, Dunn IC, Sharp PJ. Increased food intake stimulates GnRH-I, glycoprotein hormone alpha-subunit and follistatin mRNAs, and ovarian follicular numbers in laying broiler breeder hens. Domest Anim Endocrinol. 2007; 33:62-76. [PubMed: 16737793]

Clark JT, Kalra PS, Crowley WR, Kalra SP. Neuropeptide Y and human pancreatic polypeptide stimulate feeding behavior in rats. Endocrinology. 1984; 115:427-429. [PubMed: 6547387]

Clement TS, Grens KE, Fernald RD. Female affiliative preference depends on reproductive state in the African cichlid fish, Astatotilapia burtoni. Behavioral Ecology. 2005; 16:83-88.

Clutton-Brock, TH. The evolution of parental care. Princeton University Press; New Jersey: 1991.

de Lecea L, Kilduff TS, Peyron C, Gao X, Foye PE, Danielson PE, Fukuhara C, Battenberg EL, Gautvik VT, Bartlett FS 2nd, Frankel WN, van den Pol AN, Bloom FE, Gautvik KM, Sutcliffe JG. The hypocretins: hypothalamus-specific peptides with neuroexcitatory activity. Proc Natl Acad Sci U S A. 1998; 95:322-327. [PubMed: 9419374]

Fernald, RD. Hormones, Brain and Behavior. 2. Elsevier; Maryland Heights, MO: 2009. Social Regulation of Reproduction: What Changes and Why?; p. 683-691.

Fernald RD, Hirata NR. Field study of Haplochromis burtoni: habitats and co-habitant. Environmental Biology of Fishes. 1977; 2:299-308.

Fernald RD, Hirata NR. Field study of Haplochromis burtoni: Quantitative behavioural observations. Animal Behaviour. 1977; 25:964-975.

Fernald RD, Hirata NR. The Ontogeny of Social Behavior and Body Coloration in the African Cichlid Fish Haplochromis-Burtoni. Zeitschrift fuer Tierpsychologie. 1979; 50:180-187.

Flanagan CA, Chen CC, Coetsee M, Mamputha S, Whitlock KE, Bredenkamp N, Grosenick L, Fernald RD, Illing N. Expression, structure, function and evolution of GnRH receptors GnRHR1SHS and GnRH-R2PEY in the teleost, Astatotilapia burtoni. Endocrinology. 2007

Francis RC, Soma K, Fernald RD. Social regulation of the brain-pituitary-gonadal axis. Proc Natl Acad Sci U S A. 1993; 90:7794-7798. [PubMed: 8356086]

Fryer, G.; Iles, TD. The Cichlid Fishes of the Great Lakes of Africa: Their Biology and Evolution. TFH Publications; Neptune City: 1972.

Garcia MC, Lopez M, Gualillo O, Seoane LM, Dieguez C, Senaris RM. Hypothalamic levels of NPY, $\mathrm{MCH}$, and prepro-orexin mRNA during pregnancy and lactation in the rat: role of prolactin. FASEB J. 2003; 17:1392-1400. [PubMed: 12890692]

Gibbs J, Young RC, Smith GP. Cholecystokinin decreases food intake in rats. J Comp Physiol Psychol. 1973; 84:488-495. [PubMed: 4745816]

Grone BP, Maruska KP, Korzan WJ, Fernald RD. Social status regulates kisspeptin receptor mRNA in the brain of Astatotilapia burtoni. Gen Comp Endocrinol. 2010; 169:98-107. [PubMed: 20688063]

Gross MR, Sargent RC. The Evolution of Male and Female Parental Care in Fishes. American Zoologist. 1985; 25:807-822.

Gruenewald DA, Matsumoto AM. Reduced gonadotropin-releasing hormone gene expression with fasting in the male rat brain. Endocrinology. 1993; 132:480-482. [PubMed: 8419144]

Himick BA, Peter RE. CCK/gastrin-like immunoreactivity in brain and gut, and CCK suppression of feeding in goldfish. Am J Physiol. 1994; 267:R841-851. [PubMed: 8092330]

Hofmann HA, Fernald RD. Social status controls somatostatin neuron size and growth. J Neurosci. 2000; 20:4740-4744. [PubMed: 10844043]

Hoskins LJ, Xu M, Volkoff H. Interactions between gonadotropin-releasing hormone $(\mathrm{GnRH})$ and orexin in the regulation of feeding and reproduction in goldfish (Carassius auratus). Horm Behav. 2008; 54:379-385. [PubMed: 18544455]

Hu Y, Bloomquist BT, Cornfield LJ, DeCarr LB, Flores-Riveros JR, Friedman L, Jiang P, LewisHiggins L, Sadlowski Y, Schaefer J, Velazquez N, McCaleb ML. Identification of a novel 
hypothalamic neuropeptide Y receptor associated with feeding behavior. J Biol Chem. 1996; 271:26315-26319. [PubMed: 8824284]

Kauffman AS, Bojkowska K, Wills A, Rissman EF. Gonadotropin-releasing hormone-II messenger ribonucleic acid and protein content in the mammalian brain are modulated by food intake. Endocrinology. 2006; 147:5069-5077. [PubMed: 16873537]

Kauffman AS, Rissman EF. A critical role for the evolutionarily conserved gonadotropin-releasing hormone II: Mediation of energy status and female sexual behavior. Endocrinology. 2004; 145:3639-3646. [PubMed: 15105381]

Kishida M, Specker JL. Paternal mouthbrooding in the black-chinned tilapia, Sarotherodon melanotheron (Pisces : Cichlidae): Changes in gonadal steroids and potential for vitellogenin transfer to larvae. Horm Behav. 2000; 37:40-48. [PubMed: 10712857]

Lin X, Volkoff H, Narnaware Y, Bernier NJ, Peyon P, Peter RE. Brain regulation of feeding behavior and food intake in fish. Comp Biochem Physiol A Mol Integr Physiol. 2000; 126:415-434. [PubMed: 10989336]

Loucks AB, Heath EM. Dietary restriction reduces luteinizing hormone (LH) pulse frequency during waking hours and increases LH pulse amplitude during sleep in young menstruating women. $\mathrm{J}$ Clin Endocrinol Metab. 1994; 78:910-915. [PubMed: 8157720]

Maney DL, Richardson RD, Wingfield JC. Central administration of chicken gonadotropin-releasing hormone-II enhances courtship behavior in a female sparrow. Horm Behav. 1997; 32:11-18. [PubMed: 9344687]

Maruska KP, Fernald RD. Steroid receptor expression in the fish inner ear varies with sex, social status, and reproductive state. Bmc Neuroscience. 2010; 11

Matsuda K, Maruyama K, Miura T, Uchiyama M, Shioda S. Anorexigenic action of pituitary adenylate cyclase-activating polypeptide (PACAP) in the goldfish: feeding-induced changes in the expression of mRNAs for PACAP and its receptors in the brain, and locomotor response to central injection. Neurosci Lett. 2005a; 386:9-13. [PubMed: 15975713]

Matsuda K, Maruyama K, Nakamachi T, Miura T, Uchiyama M, Shioda S. Inhibitory effects of pituitary adenylate cyclase-activating polypeptide (PACAP) and vasoactive intestinal peptide (VIP) on food intake in the goldfish, Carassius auratus. Peptides. 2005b; 26:1611-1616. [PubMed: 16112400]

Matsuda K, Nakamura K, Shimakura SI, Miura T, Kageyama H, Uchiyama M, Shioda S, Ando H. Inhibitory effect of chicken gonadotropin-releasing hormone II on food intake in the goldfish, Carassius auratus. Horm Behav. 2008; 54:83-89. [PubMed: 18342861]

Matsuda K, Shimakura S, Maruyama K, Miura T, Uchiyama M, Kawauchi H, Shioda S, Takahashi A. Central administration of melanin-concentrating hormone $(\mathrm{MCH})$ suppresses food intake, but not locomotor activity, in the goldfish, Carassius auratus. Neurosci Lett. 2006; 399:259-263. [PubMed: 16503089]

McShane TM, Petersen SL, McCrone S, Keisler DH. Influence of food restriction on neuropeptide-Y, proopiomelanocortin, and luteinizing hormone-releasing hormone gene expression in sheep hypothalami. Biol Reprod. 1993; 49:831-839. [PubMed: 8218649]

Morley JE, Horowitz M, Morley PM, Flood JF. Pituitary adenylate cyclase activating polypeptide (PACAP) reduces food intake in mice. Peptides. 1992; 13:1133-1135. [PubMed: 1494495]

Mrowka W. Brood Care Motivation and Hunger in the Mouthbrooding Cichlid PseudocrenilabrusMulticolor. Behav Process. 1984; 9:181-190.

Mrowka W, Schierwater B. Energy Expenditure for Mouthbrooding in a Cichlid Fish. Behavioral Ecology and Sociobiology. 1988; 22:161-164.

Nakamachi T, Matsuda K, Maruyama K, Miura T, Uchiyama M, Funahashi H, Sakurai T, Shioda S. Regulation by orexin of feeding behaviour and locomotor activity in the goldfish. J Neuroendocrinol. 2006; 18:290-297. [PubMed: 16503924]

Narnaware YK, Peter RE. Effects of food deprivation and refeeding on neuropeptide Y (NPY) mRNA levels in goldfish. Comp Biochem Physiol B Biochem Mol Biol. 2001; 129:633-637. [PubMed: 11399499]

Oppenheimer JR. Mouthbreeding in fishes. Anim Behav. 1970; 18:493-503. [PubMed: 5498033] 
Pedrazzini T, Seydoux J, Kunstner P, Aubert JF, Grouzmann E, Beermann F, Brunner HR. Cardiovascular response, feeding behavior and locomotor activity in mice lacking the NPY Y1 receptor. Nat Med. 1998; 4:722-726. [PubMed: 9623984]

Peyon P, Saied H, Lin X, Peter RE. Postprandial, seasonal and sexual variations in cholecystokinin gene expression in goldfish brain. Brain Res Mol Brain Res. 1999; 74:190-196. [PubMed: 10640690]

Qu D, Ludwig DS, Gammeltoft S, Piper M, Pelleymounter MA, Cullen MJ, Mathes WF, Przypek R, Kanarek R, Maratos-Flier E. A role for melanin-concentrating hormone in the central regulation of feeding behaviour. Nature. 1996; 380:243-247. [PubMed: 8637571]

Renn SC, Carleton JB, Magee H, Nguyen ML, Tanner AC. Maternal care and altered social phenotype in a recently collected stock of Astatotilapia burtoni cichlid fish. Integr Comp Biol. 2009; 49:660 673. [PubMed: 21665848]

Richard D, Trayhurn P. Energetic efficiency during pregnancy in mice fed ad libitum or pair-fed to the normal energy intake of unmated animals. J Nutr. 1985; 115:593-600. [PubMed: 3998861]

Sakurai T, Amemiya A, Ishii M, Matsuzaki I, Chemelli RM, Tanaka H, Williams SC, Richarson JA, Kozlowski GP, Wilson S, Arch JR, Buckingham RE, Haynes AC, Carr SA, Annan RS, McNulty DE, Liu WS, Terrett JA, Elshourbagy NA, Bergsma DJ, Yanagisawa M. Orexins and orexin receptors: a family of hypothalamic neuropeptides and $\mathrm{G}$ protein-coupled receptors that regulate feeding behavior. Cell. 1998; 92:1. page following 696. [PubMed: 9527442]

Salaneck E, Larsson TA, Larson ET, Larhammar D. Birth and death of neuropeptide Y receptor genes in relation to the teleost fish tetraploidization. Gene. 2008; 409:61-71. [PubMed: 18191918]

Schneider JE. Energy balance and reproduction. Physiol Behav. 2004; 81:289-317. [PubMed: 15159173]

Schneider JE, Wade GN. Availability of metabolic fuels controls estrous cyclicity of Syrian hamsters. Science. 1989; 244:1326-1328. [PubMed: 2734610]

Schwartz MW, Woods SC, Porte D Jr, Seeley RJ, Baskin DG. Central nervous system control of food intake. Nature. 2000; 404:661-671. [PubMed: 10766253]

Smith C, Wootton RJ. The Cost of Parental Care in Haplochromis-Argens (Cichlidae). Environmental Biology of Fishes. 1994; 40:99-104.

Smith C, Wootton RJ. The Costs of Parental Care in Teleost Fishes. Rev Fish Biol Fisher. 1995; 5:722.

Smith CJ, Haley SR. Evidence of Steroidogenesis in Postovulatory Follicles of the Tilapia, Oreochromis-Mossambicus. Cell and Tissue Research. 1987; 247:675-687.

Smith CJ, Haley SR. Steroid Profiles of the Female Tilapia, Oreochromis-Mossambicus, and Correlation with Oocyte Growth and Mouthbrooding Behavior. General and Comparative Endocrinology. 1988; 69:88-98. [PubMed: 3360291]

Specker JL, Kishida M. Mouthbrooding in the Black-Chinned Tilapia, Sarotherodon melanotheron (Pisces : Cichlidae): The presence of eggs reduces androgen and estradiol levels during paternal and maternal parental behavior. Hormones and Behavior. 2000; 38:44-51. [PubMed: 10924286]

Tacon P. Relationships between the expression of maternal behaviour and ovarian development in the mouthbrooding cichlid fish Oreochromis niloticus. Aquaculture. 1996; 146:261-275.

Tacon P, Baroiller JF, Le Bail PY, Prunet P, Jalabert B. Effect of egg deprivation on sex steroids, gonadotropin, prolactin, and growth hormone profiles during the reproductive cycle of the mouthbrooding cichlid fish Oreochromis niloticus. Gen Comp Endocrinol. 2000; 117:54-65. [PubMed: 10620423]

Temple JL, Millar RP, Rissman EF. An evolutionarily conserved form of gonadotropin-releasing hormone coordinates energy and reproductive behavior. Endocrinology. 2003; 144:13-19. [PubMed: 12488325]

Tena-Sempere M. Roles of ghrelin and leptin in the control of reproductive function. Neuroendocrinology. 2007; 86:229-241. [PubMed: 17851226]

Trayhurn P. Thermogenesis and the energetics of pregnancy and lactation. Can J Physiol Pharmacol. 1989; 67:370-375. [PubMed: 2667730] 
Turovskaya, Y. Characterization of Neuropeptide Y (NPY) Receptor and its Expression Pattern in the African Cichlid Fish, Astatotilapia burtoni, Biological Sciences. Stanford University; Stanford: 2006. p. 42

Vergoni AV, Bertolini A. Role of melanocortins in the central control of feeding. European Journal of Pharmacology. 2000; 405:25-32. [PubMed: 11033311]

Volkoff H, Bjorklund JM, Peter RE. Stimulation of feeding behavior and food consumption in the goldfish, Carassius auratus, by orexin-A and orexin-B. Brain Res. 1999; 846:204-209. [PubMed: 10556637]

Wahab F, Ullah F, Chan YM, Seminara SB, Shahab M. Decrease in hypothalamic Kiss1 and Kiss1r expression: a potential mechanism for fasting-induced suppression of the HPG axis in the adult male rhesus monkey (Macaca mulatta). Horm Metab Res. 2011; 43:81-85. [PubMed: 21154197]

White SA, Fernald RD. Gonadotropin-releasing hormone-containing neurons change size with reproductive state in female Haplochromis burtoni. J Neurosci. 1993; 13:434-441. [PubMed: 8426222]

White SA, Nguyen T, Fernald RD. Social regulation of gonadotropin-releasing hormone. J Exp Biol. 2002; 205:2567-2581. [PubMed: 12151363]

Zhao S, Fernald RD. Comprehensive algorithm for quantitative real-time polymerase chain reaction. J Comput Biol. 2005; 12:1047-1064. [PubMed: 16241897] 


\section{Highlights}

- mouthbrooding and food deprivation both decrease ovary size and levels of androgens and estrogens

- effects of mouthbrooding and food deprivation differ for GnRH and NPY receptors

- hypocretin and cholecystokinin mRNAs are highly abundant in the brains of food-deprived females

- many, but not all, physiological changes of mouthbrooding may be consequences of food deprivation 
(A)

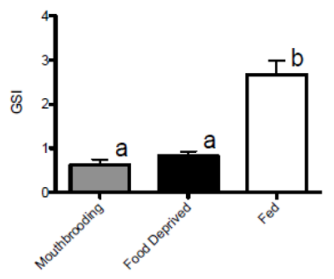

(B)

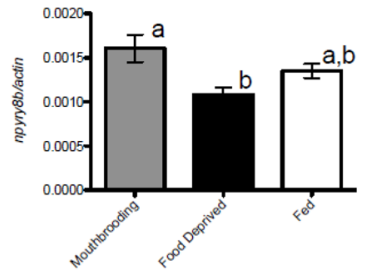

(c)

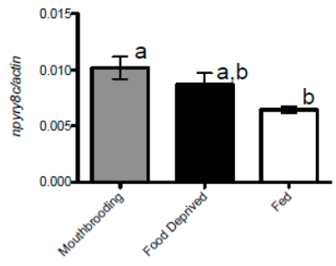

(D)

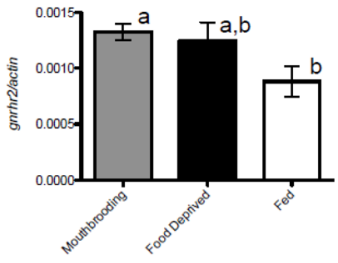

Figure 1.

Gonadosomatic index (GSI) and mRNA levels of npyry8b, npyry $8 c$, and gnrhr 2 in the brain of female A. burtoni from Experiment 1. (A) Mouthbrooding females that had their developing young removed and were then fed for 2 weeks (fed) had higher GSIs compared to brooders that were allowed to retain their young (mouthbrooding), and those that had their embryos removed and were deprived of food (food deprived). (B) Mouthbrooding females had higher levels of npyry $8 b$ mRNA compared to food deprived. Mouthbrooding females had higher levels of npyry $8 c$ mRNA compared to fed females. (C) Mouthbrooding females also had higher mRNA levels of gnrhr2 compared to fed females. Gene expression data are normalized using actin mRNA levels. Data are plotted as means \pm SE. Different letters indicate statistical differences at $\mathrm{p}<0.05$. 

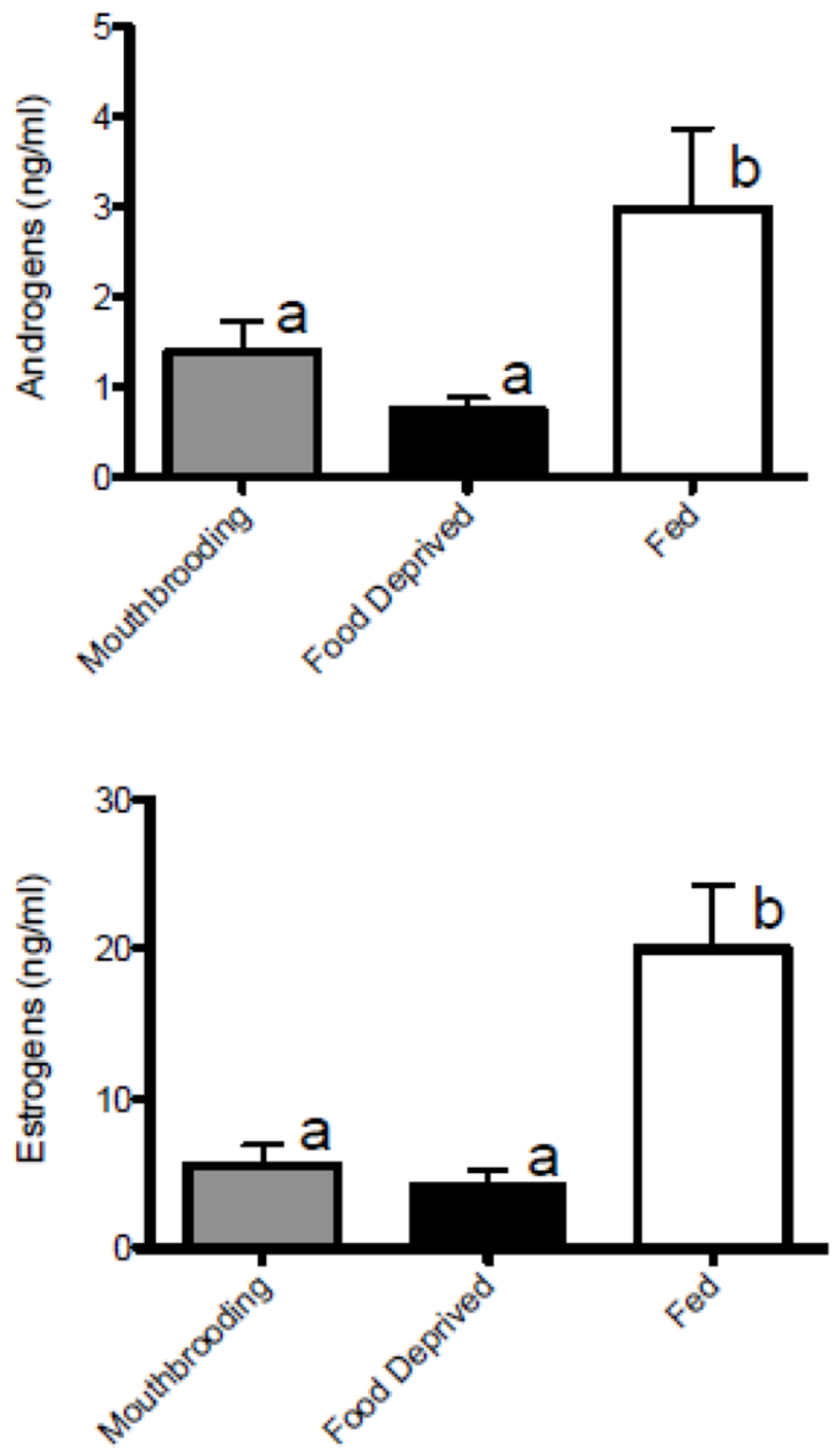

Figure 2.

Circulating estrogen and androgen concentrations in female $A$. burtoni from Experiment 1. Brooding females that had their developing young removed and were then fed for 2 weeks (fed) had higher plasma levels of both A and E compared to mouthbrooders that were allowed to retain their young (mouthbrooding), and those that had their embryos removed and were food deprived (food-deprived). Data are plotted as means \pm SE. Different letters indicate statistical differences at $\mathrm{p}<0.05$. 


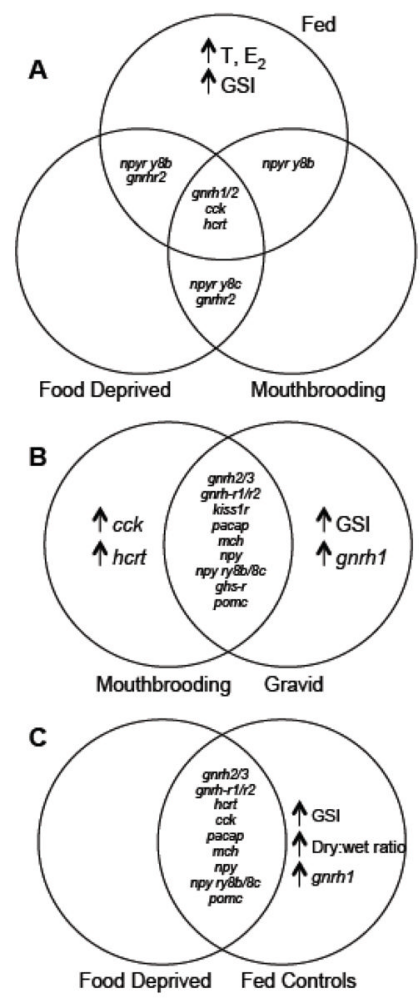

Figure 3.

Venn diagrams summarizing the results of Experiment 1 (A), experiment 2 (B), and experiment 3 (C). Physiological variables that do not differ among groups are shown inside overlapping areas of the circles. Values that are greater in one group compared to the others are shown, inside the non-overlapping area of a circle, with up arrows. 
Table 1

Real Time PCR primer sequences

\begin{tabular}{llll}
\hline$\underline{\text { Gene }}$ & Forward & $\underline{\text { Reverse }}$ & $\underline{\text { GenBank ID \# }}$ \\
gnrh1 & CAGACACACTGGGCAATATG & GGCCACACTCGCAAGA & AF076961 \\
gnrh2 & TGGACTCCTTTGGCACATCAGAGA & CTCTGGCTAAGGCATCCAGAAGAA & AF076962 \\
gnrh3 & ATGGATGGCTACCAGGTGGAAAGA & TGGATTTGGGCATTTGCCTCATCG & AF076963 \\
gnrhr1 & TCAGTACAGCGGCGAAAG & GCATCTACGGGCATCACGAT & AY705931 \\
gnrhr 2 & GGCTGCTCAGTTCCGAGTT & CGCATCACCACCATACCACT & AY028476 \\
kissir & CGTGACAGTCTACCCCCTGAA & TCCAAATGCAAATGCTGACAA & GQ860302 \\
hcrt & GCATCCTTTTGGCTGCTAA & TTCCCTCACTCCAGGGTAC & FJ871159 \\
npy & CCTTGACGGAGGCATACCC & GAGGTTGATGTAATGTCTCAGG & AY779047 \\
npyry8b & ATCCTCGTGGAGCCCTTGTTCTTT & TCATGGTCTGCTACCTGCATGTCT & JN639878 \\
npyry8c & TCAGGTCTTCTCCCTGGTGTTGAT & TCTGGAATGGGTCATTGGTGAGGA & JN639879 \\
cck & ATGCATCCTAACTTGGTGAGCTGG & TCTCTGGTTTCACTGGGTATGCCT & CN471180 \\
mch & CATCATCTTTGCTGCAGCGCTCTT & AAAGCATCCTTCTCCAAGGAGCCA & X81144 \\
pacap & ATAGAGCCTTGAGGAGATCCTGG & CGTCAGCTGCACGAATTGTCAT & EU523856 \\
pomc & AAGTGTGGAGGATGTGTCCTGTGT & TGGATGCACTCCATCATGTTGCTC & AF116240 \\
g.3pdh & GCAGCAGCCACCATGTCAAGAC & GCAGACACTTCACCACGGTAACG & AF123727 \\
actin & CGCTCCTCGTGCTGTCTTC & TCTTCTCCATGTCATCCCAGTTG & JF826504 \\
\hline & & &
\end{tabular}




\section{Table 2}

Female whole brain mRNA levels normalized to actin.

\begin{tabular}{lrrrl}
\hline Gene & Mouthbrooding & $\underline{\text { Food Deprived }}$ & $\underline{\text { Fed }}$ & $\underline{\text { P value }}$ \\
gnrh1 & $0.0282 \pm 0.0113$ & $0.0174 \pm 0.00651$ & $0.0269 \pm 0.0105$ & 0.0514 \\
gnrh2 & $0.00223 \pm 0.000811$ & $0.00246 \pm 0.000748$ & $0.00216 \pm 0.000752$ & 0.789 \\
gnrhr2 & $0.00132 \pm 0.000239$ & $0.00124 \pm 0.000474$ & $0.000881 \pm 0.000390$ & $\mathbf{0 . 0 3 5 0}$ \\
hcrt & $0.00332 \pm 0.00132$ & $0.00357 \pm 0.00144$ & $0.00343 \pm 0.000914$ & 0.914 \\
npyry8b & $0.00161 \pm 0.000480$ & $0.00108 \pm 0.000243$ & $0.00135 \pm 0.000230$ & $\mathbf{0 . 0 4 7 4}$ \\
npyry8c & $0.0102 \pm 0.00300$ & $0.00865 \pm 0.00313$ & $0.00644 \pm 0.000853$ & $\mathbf{0 . 0 1 4 2}$ \\
cck & $0.0397 \pm 0.0108$ & $0.0402 \pm 0.0173$ & $0.0339 \pm 0.00747$ & 0.528 \\
\hline
\end{tabular}

Values reported as mean $\pm \mathrm{SD}(\mathrm{N}=10$ Mouthbrooding, 9 Food Deprived, 8 Fed). One-way ANOVA test and Tukey post hoc test used for gnrh1, $c c k$, and hcrt. Kruskal-Wallis test followed by Dunn's post hoc test used for gnrh2, gnrhr2, npyry8b, npyry $8 c$ 
Table 3

Gravid and mouthbrooding female mRNA levels normalized to $g 3 p d h$.

\begin{tabular}{llll}
\hline Gene & Brooding & Gravid & $\underline{\text { P value }}$ \\
gnrh1 & $0.0160 \pm 0.0034$ & $0.0234 \pm 0.0061$ & $\mathbf{0 . 0 3 7 9}$ \\
gnrh2 & $0.00736 \pm 0.00439$ & $0.00692 \pm 0.00455$ & 0.857 \\
gnrh3 & $0.00927 \pm 0.00207$ & $0.00960 \pm 0.00208$ & 0.753 \\
gnrhr1 & $0.0158 \pm 0.0056$ & $0.0213 \pm 0.0115$ & 0.238 \\
gnrhr2 & $0.00101 \pm 0.00026$ & $0.00107 \pm 0.00029$ & 0.688 \\
kiss1r & $0.00130 \pm 0.00019$ & $0.00140 \pm 0.00027$ & 0.548 \\
hcrt & $0.00269 \pm 0.00059$ & $0.00212 \pm 0.00044$ & $\mathbf{0 . 0 4 6 2}$ \\
npy & $0.0623 \pm 0.0111$ & $0.0612 \pm 0.0116$ & 0.834 \\
npyry8b & $0.00432 \pm 0.00087$ & $0.00369 \pm 0.00082$ & 0.156 \\
npyry8c & $0.00536 \pm 0.00136$ & $0.00512 \pm 0.00101$ & 0.701 \\
cck & $0.0369 \pm 0.0106$ & $0.0233 \pm 0.0057$ & $\mathbf{0 . 0 0 1 9}$ \\
mch & $0.0151 \pm 0.0029$ & $0.0198 \pm 0.0102$ & 0.6454 \\
pacap & $0.0906 \pm 0.0220$ & $0.0757 \pm 0.0095$ & 0.1049 \\
pomc & $0.195 \pm 0.268$ & $0.240 \pm 0.360$ & 0.782 \\
\hline
\end{tabular}

Values are reported as mean $\pm \mathrm{SD} ; \mathrm{N}=8$; two-tailed t-test (p values $<0.05$ in bold). P values for $g n r h 1, c c k$, mch, and pacap refer to MannWhitney test and all others refer to ANOVA. 


\section{Table 4}

Brain mRNA levels normalized to $g 3 p d h$ in food deprived and fed females.

\begin{tabular}{lllll}
\hline Gene & Food Deprived & $\underline{\text { Fed }}$ & $\underline{\text { T stat }}$ & $\underline{\text { P value }}$ \\
gnrh1 & $0.0203 \pm 0.00532$ & $0.0397 \pm 0.0124$ & 4.0596 & $\mathbf{0 . 0 0 1 1}$ \\
gnrh2 & $0.00610 \pm 0.00204$ & $0.00470 \pm 0.00196$ & 1.405 & 0.182 \\
gnrh3 & $0.0164 \pm 0.0143$ & $0.0118 \pm 0.00485$ & 0.853 & 0.574 \\
gnrhr1 & $0.0187 \pm 0.0155$ & $0.0132 \pm 0.00669$ & 0.905 & 0.798 \\
gnrhr2 & $0.0143 \pm 0.0153$ & $0.00998 \pm 0.00568$ & 0.751 & 0.879 \\
hcrt & $0.0110 \pm 0.0154$ & $0.00532 \pm 0.00272$ & 1.026 & 0.322 \\
npy & $0.124 \pm 0.0323$ & $0.116 \pm 0.0185$ & 0.639 & 0.279 \\
npyry8b & $0.0158 \pm 0.0133$ & $0.0111 \pm 0.00389$ & 0.974 & 0.5737 \\
npyry8c & $0.0391 \pm 0.0367$ & $0.0431 \pm 0.0680$ & 0.147 & 0.4418 \\
cck & $0.0474 \pm 0.0271$ & $0.0343 \pm 0.00385$ & 1.358 & 0.463 \\
mch & $0.0375 \pm 0.0176$ & $0.0377 \pm 0.0170$ & 0.0263 & 0.979 \\
pacap & $0.0505 \pm 0.00532$ & $0.0481 \pm 0.00596$ & 0.835 & 0.418 \\
pomc & $0.0206 \pm 0.0285$ & $0.0101 \pm 0.00522$ & 1.027 & 0.574 \\
\hline
\end{tabular}

Values reported as mean $\pm \mathrm{SD} ; \mathrm{N}=8$. Two-tailed t-test was used for $g n r h 2, h c r t, m c h$, and pacap. Mann-Whitney test was used for gnrh1, gnrh3, gnrhr1, gnrhr2, npy, npyry $8 b$, npyry $8 c, c c k$, pomc (p values $<0.05$ in bold) 